\title{
IS GOD A PHENOMENON? A DIALOGUE BETWEEN KIERKEGAARD AND JEAN-LUC MARION $^{1}$
}

\author{
Wellington José Santana (PUCGO) ${ }^{2}$ \\ wellsantana@bol.com.br
}

\begin{abstract}
The present article analyses critically the paradox between the radical phenomenon claimed by Camus, Sartre, and others philosophers, and Marion's new concept named saturated phenomenon. While the concept of God, by definition, must surpass the realm of empiricism, perhaps the saturated phenomenon may shed light over what God must be: Excess. Although the new concept does not refer directly to God, I will argue that Kierkegaard's paradox gives ground to reflect about whether or not $\mathrm{He}$ can be thought as Excess of excess, despite of the trap of the language we're immersed in. Is it possible to analyze the divinity following phenomenological footsteps?
\end{abstract}

Key-words: Paradox; Saturated phenomenon; freedom; Excess.

\section{Introduction}

Every time we look at the universe we feel how small and insignificant we are compared to how vast it is. At the beginning people used to think that the earth was the centre of the universe and played a very important role in our lives. In fact, God has chosen this tiny planet to create humanity. However, after a long period of historical and sci-

\footnotetext{
${ }^{1}$ Recebido: 29-05-2017/ Aceito: 14-09-2017/ Publicado on-line: 12/04/2020.

${ }^{2}$ Wellington José Santana é professor da Pontifícia Universidade Católica de Goiás, Goiânia, $\mathrm{GO}$, Brasil.
} 
entific development, our understanding was turned upside down when science demonstrated that Earth is not, and will never be, important at all to the universe. Little by little Earth itself will stop rotating on its axis and will lose the magnetic field that protects us from the dangerous radiation from the sun. Earth will be no more. The sun will eventually run out of fuel, expand and eventually explode creating a supernova, a new star. However, before that apocalyptic event takes place, all surrounding planets will be blown off and the universe will not remember that we existed. Now when we think about the meaning of our lives, we may be very troubled that our hopes and dreams, struggles and achievements do not really mean a lot in a big scale. The universe does not care if you live or die, if you have a university degree or not, if you suffer or are unhappy. So the question that arises is, why should we live or die?

Kierkegaard, in addition to being very interested in the concept of irony raised by Socrates ${ }^{3}$, is captivated by what the meaninglessness of life and its outcome. Since this is not a modern phenomenon that human being has to face, it must play an important role in his life. What is the place God plays in this old and modern problem? What is the relationship between lack of meaning and nihilism? Amazingly, this was a problem in Kierkegaard's time and still continues today and I shall analyze it critically now and relate it to the modern problem of the gift raised by Jacques Derrida and Jean-Luc Marion.

\footnotetext{
${ }^{3}$ Søren Kierkegaard, The Concept of Irony, (New York: Harper and Row publishers, 1965), 185
} 


\section{FACING THE PARADOX: IS GOD A PHENOMENON?}

Irony usually has its form shaped by subjectivity ${ }^{4}$ which, in the time of Socrates, represented a specific value and meaning - one which was rejected by his fellow friends. However, Kierkegaard assumes a new form of subjectivity that's grounded in the reflection's reflection. While the Enlightenment focused on the faculty of the reason raised by philosophers like Descartes and Kant, in which the main purpose was to criticize the Church and the reigning political order, the subjectivism of its focus is, instead, on emotion and feeling. This is also an issue brought about by the Romanticism, a movement that arose in France, England and Germany in the second half of the $18^{\text {th }}$ century.

However, to be able to acknowledge something as science one must be attracted to what can be proved, but will end up acknowledging that sometimes, reason is unable to provide answers to all my inquiries. Here my emotions truly emerge and show that I am not only about brain, but also about heart. I am not a ruthless machine but I do have inward emotions that lead me to decide what is better for me and for my own life, even if this decision conflicts with reason. An individual can be cultivated and I can make a room for further relationship. Here one can really show off one's true self - one's soul - as something as profound as the universe and can speak straight from the heart.

Being ironic is somehow a way of overtaking the world and being smarter than it. By utilizing the irony, one may

\footnotetext{
${ }^{4}$ Søren Kierkegaard, concluding unscientific postscript, (Princeton: New Jersey Princeton University Press, 1968), 67
} 
realize that everything is vanity ${ }^{5}$, transient in comparison to what is really important, namely God. He is absolute, omniscient and everything else is regarded as relative and finite - in short, is vanity. Outside God there are no absolutes. Here the ironist is not an nihilist but, rather, someone that can take seriously the fact that nothing is real, except God. Like the believer, the ironist really believes that the truth can set him free from this world, from hypocrisy.

Kierkegaard is aware of one of the leading philosophers of his time, namely Hegel. His doctrine was on the rise in Denmark and Kierkegaard was his fierce opponent because Hegel never really cared about subjectivity. In order to explain the situation of a specific person he utilizes the word existence when the values of his declining society were crumbling. Despite the fact that we have no clear picture of what the future will hold, Kierkegaard asserts that we must construct that future relying on the subject and his struggles. Objectivity therefore, becomes the true. It is irrelevant to know the world without knowing oneself as subject.

Another important word for the purpose of this work is "paradox," a concept raised by Kierkegaard in his Philosophical Fragments in which he points out that the Christian doctrine of Incarnation remains a real challenge for human understanding. The unknown God wanted to make himself known by the Revelation and the infinite and eternal Lord became finite and temporal with Incarnation. This is an ab-

\footnotetext{
${ }^{5}$ Ecclesiastes 1:14

${ }^{6}$ Søren Kierkegaard, Fear and Trembling, (Princeton: Princeton University Press, 1974), 80. This is the paradox that does not permit mediation. What is contradictory is contradictory. This is the way faith must be treated.
} 
solute paradox ${ }^{7}$ that the human mind cannot grasp or think or explain. However, one must accept it by the virtue of faith. The only thing people should understand about the paradox is that it is paradox ${ }^{8}$ and therefore, outside of all comprehension. This being said, it does not mean reason has no role in professing the faith in something so high. It does so in recognizing the greatness of God. With the doctrine of the absolute paradox, Kierkegaard clearly wants to insist that the Revelation is an example of an absolutely fixed, irreducible dichotomy that cannot be mediated. Kierkegaard resists seeing Christianity as a doctrine made up of arguments and discursive demonstration. Instead, he views it as an exercise of contradiction. The contradiction is the heart of Christianity presumably because it states that the eternal became temporal and somehow contingent, the infinite finite and his Philosophical Fragments bring this into focus. In one word, Christianity, or the God - since Kierkegaard himself never referred to Jesus but simply to "the God" - is never to be comprehended by human capacity, but must be accepted inwardly as truth. This is the reason why subjectivity is so important to comprehend Kierkegaard's philosophy. Instead of formulating dogmas and doctrines, Christians should engage themselves in accepting the absurd and the contradiction of believing and avoid creating creeds. Just as Kierkegaard wants to introduce people to Christianity in which no conclusive statement can be drawn, so too is inconclusiveness the goal of Plato's dialogue Hippias Major. This is one of Plato's so-called aporetic

\footnotetext{
${ }^{7}$ Søren Kierkegaard, Philosophical Fragments, (Princeton: Princeton University Press, 1974), 59

${ }^{8}$ Kierkegaard, Philosophical Fragments, 72
} 
dialogues intended to introduce people to the concept of beauty. After many failed attempts to define beauty, the discussion ends with no conclusion. In the same way Christianity is not to be used to draw conclusions because the aporia of faith is beyond any conclusion. The better path to live Christianity is within one's own soul.

Contradiction, therefore, is required for faith. This is a true way of revealing the essential part of being Christian, which is divine and human together. ${ }^{9}$ True Christian faith involves no explanation in order to clarify some aspects of faith. What synods and theologians attempted to do is a mistake. Let the mystery remain as such even if this might bring persecution, torture or even death for the belief. One has to be prepared for martyrdom or whatever may come.

Kierkegaard doesn't attempt to teach any positive doctrine about what Christianity is, or what God is, just as Socrates doesn't attempt to teach a single straightforward definition of beauty. Instead, the idea of Christianity as paradox and the concept of beauty - so difficult to define are themselves problematized. Kierkegaard aims to speak against the leading theologians at the time who sometimes made Christianity so easy to follow and who forgot the par$\operatorname{adox}^{10}$ of the cross that was about suffering and distress. He

\footnotetext{
${ }^{9}$ Søren Kierkegaard, Training in Christianity, (Princeton: New Jersey Princeton University Press, 1967), 83-85. Here Kierkegaard makes clear that the contradiction is the engine that keeps faith in the right path. Impossibility to understand and grasp what has been revealed, far from being a stumbling rock for humanity to accomplish the eternal life, is the only way. Every time theologians and philosophers attempt to explain something, they take way the essence of being Christian. ${ }^{10}$ Søren Kierkegaard, Fear and Trembling (Princeton: New Jersey Princeton University Press, 1968), 66. "Faith is precisely this paradox, that the individual as the particular is higher than the universal, is justified over against it, is not subordinate but superior - yet in such a way, be it observed, that it is the particular individual who, after has been subordinate as the particular to the universal, now through the universal becomes the individual who as the particular is superior the uniCont.
} 
believes that their conception of Christianity is misguided and even corrupt. People need to realize that following God does not involve my own and perhaps mistaken view of the mystery, shaping it to my way of living and, therefore, making God in my image and likeness. Rather, we must regard and contemplate the mystery, the absurd and contradiction $^{11}$ - the core of faith - in awe, even when this may mean having to embark on a difficult and stressful path.

Kierkegaard believed that Socrates' critical disposition could be used to undermine the different positive doctrines about Christianity and help us to return to the paradox, the absurdity and the contradiction that's intrinsic to Christianity. On the one hand, Kierkegaard's view of Christianity as something that's fundamentally tied to the individual subject is highly attractive to many people today. There seems to be something intuitively correct about focusing on the inwardness and subjectivity of the individual when we're talking about Christianity or religion in general. People feel an inward freedom when their voices are taken into account. Kierkegaard has a negative view of people as a collective unit such as a political party, a political lobby or interest group or political opinion. He believes that this distorts or even destroys the voice of the individual because one does not dare to oppose the voice of the majority for fear of being subject to its criticism.

\footnotetext{
versal, for the fact that the individual stands in absolute relation to the absolute."

${ }^{11}$ Kierkegaard, Concluding unscientific postscript, 312
} 


\section{GOD AND HUMANITY - DISTANCE AND CLOSENESS}

Kierkegaard's unique way of approaching divinity and humanity set him on a different path. The last year of his life - 1854-1855 - Kierkegaard directed a violent attack at the Anglican Church ${ }^{12}$ because according to him, priests and bishops have been convenient to please the crown instead of pleasing Jesus and the new revelation set by Jesus. Perhaps Derrida would have said the same thing. He pointed out religion is either responsibility or is nothing at all. ${ }^{13}$ The Church at the time, according to Kierkegaard, was corrupted by words and the way priests lived and spoke were evidence of the institution's corruption. This allowed him to point out the real difference between God and humanity and I will argue that this line of argument will suffice to relate him with Marion and the problem of the gift. Who is God and who is human? First of all, Kierkegaard notes that there is no possibility of a direct communication between God and man. ${ }^{14}$ This is to emphasize how high and unrecognizable he is and how human and limited is humanity. There is nothing that allows me to compare what God is to

\footnotetext{
${ }^{12}$ Kierkegaard, Concluding unscientific postscript, 327: Kierkegaard writes: "The visible Church has suffered so broad an expansion that all the original relationship have been reversed. Just as once required energy and determination to become a Christian, so now, though the renunciation be not praiseworthy, it requires courage and energy to renounce the Christian religion, while it needs only thoughtlessness to remain a nominal Christian [...] under such circumstances in Christendom (the misunderstanding of speculative philosophy on the one hand, and the presumption that one is a Christian as a matter of course on the other) it becomes more and more difficult to find a point of departure.

${ }^{13}$ Jacques Derrida. The Gift of Death, Second Edition $\mathcal{E}$ Literature in Secret, (Chicago, University Of Chicago Press, 2007), 5

${ }^{14}$ Kierkegaard, Training in Christianity, 137: Kierkegaard writes: "The true God-man cannot become direct recognizable but direct recognizableness is what merely humanity, what the men to whom he came, would pray and implore of him as the great alleviation."
} 
what humans are.

God is so different from us that when we think about the difference, it causes despair since we want to live the infinite, ${ }^{15}$ but we're unable to. Despair also arises from the lack of possibility when we attempt to find a way out of the disappointment and try to find peace in order to soothe our spirit. However, no matter what we do, God is so different that we simply cannot have direct access to him and this may lead us to remain in despair, except for he who has faith. ${ }^{16}$ Eternal happiness and the historical knowledge have nothing in common, and achieving a mediation between the two elements is impossible. Even if it were possible to collect or put together the set of finite things, the set would be unable to reach the infinity. The distance between God and man is unapproachable. ${ }^{17}$ This is the reason why Kierkegaard does not endorse any attempt to grasp God. Actually, we can neither comprehend God nor prove his existence. ${ }^{18}$ Accepting God's existence implies that we could finish listing the events in the natural order of things and, simultaneously, somehow it proves the list would be incomplete. ${ }^{19}$ Every attempt to put God into our understanding will fail and may create an illusion of what we understand God to be. Existence may explain the deeds, but

\footnotetext{
${ }^{15}$ Søren Kierkegaard, The Sickness unto Death, ((Princeton: New Jersey Princeton University Press, 1969), 166

${ }^{16}$ Kierkegaard, The Sickness unto Death, 57

${ }^{17}$ Kierkegaard, Philosophical Fragments, 58: "God is absolute different."

${ }^{18}$ Michael Watts, Kierkegaard (Oxford, Oneworld publications, 2003), 91

${ }^{19}$ Kierkegaard, Concluding unscientific postscript, 107. "An existential system cannot be formulated. Does this mean that no such system exists? By no means; nor is this implied in our assertion. Reality itself is a system - for God; but it cannot be a system for any existing spirit. System and finality correspond to one another, but existence is precisely the opposite of finality."
} 
deeds may be unable to explain existence. In fact, he who exists is greater than the deeds. God himself cannot be proved precisely because he is beyond any capacity of comprehension. Levinas states something similar when he writes that it is relation with that which always slips away. ${ }^{20}$ In his way Levinas is saying that there's something about God we will never be able to comprehend totally because just when we think we've achieved understanding, we actually haven't. God, therefore, slips away every time we attempt discussions about him, and he's never in our presence.

God is so different than a human being, so totally other, Kierkegaard notes, that we may think we're right in demanding God make himself understood and be reasonable towards us. After all, we're his creatures. Kierkegaard affirms that we're always dealing with God in the wrong way. ${ }^{21}$

There is something that unites both Marion and Kierkegaard: the idea that humanity is unable to trap God into human understanding. Although Kierkegaard is probably unaware of the trap of even calling God a supreme being, we must consider him a true protester of the way God has been treated, especially by priests and bishops of his time. God is not strange or an alien since he himself became con-

\footnotetext{
${ }^{20}$ Emmanuel Levinas, Ethics and Infinity: Conversations with Philippe Nemo, (Duquesne University Press, 1985), 67

${ }^{21}$ Søren Kierkegaard, Either/Or II, (Princeton: New Jersey Princeton University Press, 1987), 349. He writes: "and yet, if you must of necessity acknowledge it, then there is indeed nothing upbuilding in the thought that you are always in the wrong, for it was stated that the reason it can be painful in the one situation to be in the wrong, in the other upbuilding, is that in the one case a person is forced to acknowledge what in the other case he wishes to acknowledge. Thus it is true that in your relationship with God you would be freed from the contradiction, but you would have lost the upbuilding; and yet it was precisely upon this that we wanted to deliberate: The upbuilding in our always being in the wrong in relation to God."
} 
tradiction $^{22}$ by incarnation. I argue that we might use the same word to define this uneasy feeling philosophers and theologians' portrayal of God generates: Excess. God's selfdisclosure made by Jesus is the ultimate excess. In Abraham's episode, ${ }^{23}$ God, the wholly other, is seen in such a way that Abraham was totally unaware about God's plan. He never wanted him to kill his son, but only display proof of the faith that Abraham claimed to have for patriarchs and prophets. God's mind is absolutely unimaginable. There is an infinite qualitative difference between the other and the wholly other, or in Kierkegaard's words "between God and human being there is an eternal essential ${ }^{24}$ qualitative difference" 25 or "the most chasmic qualitative abyss." 26

\section{SATURATED PHENOMENON}

The first version of saturated phenomenon was written by Marion in the paper Reduction and Givenness and a more elaborated version followed in Being Given. Phenomenon has the right to show itself in its fullness and radical way. It is important that here intuition plays an important role, but not a fundamental one. In fact, Husserl is not con-

\footnotetext{
22 Corinthians 5:21. "He made Him who knew no sin to be sin on our behalf, so that we might become the righteousness of God in Him." This is the way Saint Paul would have referred to Christ who became a sin for human being. In short, he became a contradiction in order to open the doors of eternity to all.

${ }^{23}$ Kierkegaard, Fear and Trembling, 56

${ }^{24}$ Simon D. Podmore. Kierkegaard and the self before God, (Indianapolis: Indiana University Press, 2011), 45

${ }^{25}$ Søren Kierkegaard. Upbuilding Discourses, (Princeton: New Jersey Princeton University Press, 1993), 287

${ }^{26}$ Kierkegaard. The Sickness unto Death, 122
} 
cerned solely with intuition in the Kantian sense, but with the givenness and evidence brought by it. The essence of the phenomenon is the phenomenon itself even when it is clear that no intuition is necessarily involved. Marion argues that givenness is not the same as intuition because it is perfectly possible that something given does not fulfill intuition. ${ }^{27}$ Reduction, as it has been pointed out above, is the path that normally Husserl used to fill the categories by Kant that sometimes seemed to be empty. In fact, Kantian doctrine about the noumenon [the thing in itself] hides what is essential in the phenomenon itself precisely because noumenon will never be able to be known. It seems to be an empty category that Husserl wants to fill solely with phenomenon. For Husserl, there is no noumenon because what really exists is the/a phenomenon that donates itself in its fullness without hiding anything.

Marion, then, affirms that phenomena do not give themselves in the same degree. There are varying degrees of givenness and some do show more than others. If phenomenon is what appears, either in reflection or revealed, we might say that it is conveyed by consciousness that acknowledges and defines what has been captured by the senses. Therefore, consciousness is directed toward something that signifies what signifies and may develop a connection with the consciousness. However, although being related, consciousness and phenomenon are to be thought of in the realm of immanence and may not be related to metaphysics. To give itself is to show itself. ${ }^{28}$ It is proper of

\footnotetext{
${ }^{27}$ Jean-Luc Marion. Being given (Stanford, Stanford University Press, 2012), 82

${ }^{28}$ Jean-Luc Marion, Being given (Stanford, Stanford University Press, 2012), 61: "The decision to Cont.
} 
the phenomenon, considered in its essence, to show itself, to manifest only as a given. In short, phenomenon must appear as such not as the appearing of something else, but rather of itself. Therefore, this appearance has no a priori because what gives itself, shows itself. Marion writes

Showing itself therefore amounts to giving itself. The fold of givenness, in unfolding itself, shows the given that givenness dispenses. For the phenomenon, showing itself is equal to unfolding the fold of givenness in which it arises as a gift. Something and giving itself play in the same field - the fold of givenness, which is unfolded in the given. What remains is to verify in the details of the phenomenon how its phenomenological primacy is carried out. ${ }^{29}$ :

This concept was precisely what Husserl thought that phenomenon should be and based upon what he said, Marion develops further considerations about the meaning of phenomenon as such. Husserl points out that metaphysics is excluded from his horizons, but Marion is not totally convinced about this.

However, Marion developed a new concept of phenomenon that not only occupies the immanence world, but also goes beyond. It is called saturated phenomenon. In order to address the question one might understand the limit of the givenness and then what does it mean, saturated givenness. We probably all have had the sense of being overwhelmed by something and this can lead toward a

define phenomenality in terms of givenness falls prey to one last suspicion, seemingly quite formidable: I am not just playing on the ambiguity of a signifier [givenness in English, donation in French] in order to claim to reach a signified that in fact has not been constructed or justified? I would be speaking of givenness as a unified concept, while a simple analogy would enable us to establish a network of terms that remain equivocal, as would their usage by different authors."

${ }^{29}$ Marion, Being given, 70 
sense of torpor or numbness. The flux of images and information and a sheer culture of choices make us think about our limits and what makes us so unpredictable. We are living in a culture of excess which might make us understand the true meaning of the word saturated. Let's consider a painting that appears as a single phenomenon as presenting our consciousness, and let's consider how the painting has been painted. How can one describe both the painting itself as well as the way that it has been painted? Can phenomenon itself be described as only what we can achieve by our senses? Marion affirms that eventually this phenomenon is much more than the sum of its dots and seems to subsist beyond its visibility. ${ }^{30}$ There is something to see on top of the material thing that tells more than our consciousness can initially grasp, something invisible that defies our limited vision and meaning. Every spectator may have a different perception of the same painting. Therefore, we ought to see the invisible subsisting in what is visible and it seems that the beauty of the phenomenon painting appears independently of both the painting itself and its being. The beauty of the work of art is such that, the less important is the material thing, more the meaning for the spectators. The feeling that arises from the contemplation of the phenomenon is connected with it, but surpasses it in the very moment a perception has taken place. Horner writes: ${ }^{31}$

Marion offers the possibility that the work of art, far from capturing the truth of the being, actually frees itself

\footnotetext{
${ }^{30}$ Marion, Being given, 62

${ }^{31}$ Horner, Rethinking God as a Gift, 119
} 
from it. In the end, the painting is not. The paradox of the painting is that it is not, and yet it appears all the more. In what, then, does the phenomenality of the painting consist? [...] the nonvisual analogy is used to express something that cannot be expressed in terms of real visibility.

Husserl admits that there is a phenomenon without conditions which is unrepeatable. As I showed above, every phenomenon given adds something invisible, not necessarily metaphysical, but something beyond what the phenomenon wanted to show. The phenomenon given is absolutely irrevocable because it is unique and cannot be repeated. Marion, therefore, sees here room for the introduction of a specific type of phenomenon that is completely different, and he asks whether it is possible to envisage what he called unconditioned, that is having no horizon or limits, irreducible to what I am. Such phenomenon would have no determination and would not be limited to our intuition, but rather, would be saturated intuition. The saturated phenomenon does not relate to Kantian categories because it exceeds them.

Marion states that the term first philosophy that came from Aristotle is more suitable to apply not for ousia ${ }^{32}$ but for the phenomenon that goes beyond. He sheds light into our normal phenomena that we would never have thought could surpass us in such an intense way. If one takes, for instance, a room and attempts to saturate it, the walls are overcome and the poignant impact of every part of the room becomes evident and visible. The pure visibility, then,

\footnotetext{
32 Jean-Luc Marion. In Excess - Studies of saturated phenomena, (New York: Fordham University Press, 2002), 6
} 
gives room to what rises up before us, irresistible, silent, and invisible. Marion points out:

I am therefore proposing to follow another way to accede to such an invisible and to justify it phenomenologically: to consider phenomena where the duality between intention (signification) and intuition (fulfillment) certainly remains, as well as the noetic-noematic correlation, but where, to the contrary of poor and common phenomena, intuition gives (itself) in exceeding what the concept (signification, intentionality, aim, and so on) can foresee of it and show. I call these saturated phenomena, or paradoxes. They are saturated phenomena in that constitution encounters there an intuitive givenness that cannot be granted a univocal sense in return. It must be allowed, then, to overflow with many meanings, or an infinity of meanings, each equally legitimate and rigourous, without managing either to unify them or to organize them ${ }^{33}$.

Here Marion refers not to the usual phenomenon, but that before which one remains speechless recognizing the greatness that exceeds all subjective interpretation. The idol and the saturated phenomenon cannot be together. They have different paths, purposes and cannot be looked at with the same eyes. Saturated phenomena do not give themselves in univocal ways, and they never will be mastered by a viewer. In this regard, these phenomena are considered paradox. They multiply their own meaning and do not pursue any personal fulfillment or fill their own self. I do not assign them any content or significance, but, rather, they produce dissimilar effects on me opening my spirit to what is completely invisible. There is an amalgam, a mixture of

\footnotetext{
${ }^{33}$ Marion, In Excess - Studies of saturated phenomena, 74
} 
what I feel or what these phenomena produce in me in terms of feeling and my desire to grasp them and understand them. My consciousness is direct to what is shown to me and my mind remains full. Consequently, the saturated phenomena open the spirit to the invisible without measure. Saturated phenomenon is related to excess inasmuch as the significance does not remain univocal and what is given is not only what I can see. Phenomenon, as thought by Husserl, only shows itself and does not intend or aim to show anything else. What the phenomenon is, is what is in my intention. However, saturated phenomenon shows itself as visible as someone who opens a window, but the true meaning can be found after we surpass the window. The intention is really to show more since the denotation exceeds what the phenomenon itself is meant to be. Saturated phenomenon is the phenomenon beyond the phenomenon. ${ }^{34}$

Among all phenomena, there is one that has special significance: the face. Inspired by Levinas, Marion envisages the face not as a physical organ, but the expression of the spirit. The face envisages me while I envisage the face. Thus such phenomenon does not reflect intuition, but surpasses it. At this stage, the gaze is completely impotent to bear what the meaning is because the face, as saturated intuition, brings bedazzlement. ${ }^{35}$ As soon as the phenomenon gives itself, it does without reserve, without limit while the

\footnotetext{
${ }^{34}$ Marion, In Excess - Studies of saturated phenomena, 119: Marion writes: "there are, therefore, phenomena that I call saturated, where the excess of intuition over signification censures the constitution of an object and, more radically, the visibility of a unified and defined spectacle. Among these paradoxically invisible phenomena, I have privileged the face, because the analyses of Levinas have acquired an exemplary phenomenological status

${ }^{35}$ Jean-Luc Marion. The visible and the revealed, (New York: Fordham University Press, 2008), 37
} 
saturated phenomenon exceeds even what was supposed to be the total. This means that when I encounter a saturated phenomenon, I am completely unable to predict or anticipate the outcome. It becomes clear that Marion wanted to include the "self" as part of contemplating the phenomenon that is always preceded by the other, or the face, even if the other is God.

Kierkegaard also foresaw the meaning of being stricken by phenomena that bring suffering and distress to be affirming that faith in God, the wholly other, is the ultimate answer for human being. There are phenomena destined to partake our lives as humans indicating only what causes us to suffer. However, there are also those destined to show us how he, who has faith, has in God the maximum spiritual gift one might get. While for Kierkegaard, God is the ultimate gift, Marion attempts to show the very distinction between a normal phenomenon and the one which surpasses our expectations. Looking at Marion's work, I will argue that he does not necessarily refer to the religious phenomena, ${ }^{36}$ but he does not exclude it either. This may give room to affirm that the saturated phenomenon par excellence might be identified with a transcendent one.

\footnotetext{
${ }^{36}$ Marion wanted, in principle, to remain the sphere of phenomenology when he engages in the saturated phenomenon sphere. He has been accused of doing theology, instead of philosophy by authors like Janicaud and others. When he wrote Being Given it's clear that Marion responds to their criticisms stating that his writings are about philosophy. This is true insofar as he does not talk about theology, except in God without Being in which he pictures clearly the theology of Eucharist. As far as saturated phenomenon is concerned, it must remain in phenomenology. However, I certainly see an open door to a theological turn, and I shall refer to this later on.
} 


\section{Derrida, MARION AND Negative TheOlogy}

God - as I have pointed out - does not fit into our narrow frame of understanding. None of our efforts are enough to make him present or speak properly about him. How should human being approach him or speak about him? If someone decides to elaborate declarations or statements about him saying that God is supreme, infinite, allpowerful, or stating that God is beyond limits, this approach would still be insufficient and would not be able to reflect God's essence at all. However, people do need something through which they could refer to the Most High. Affirmation demands a subject and can carry out a feeling of attaining what is unattainable or capturing the essence of what God himself is while negation does not claim that much. By negation, one is not posing a limit to God or saying what his nature should be. Instead, one is doing precisely the opposite and avoiding conceptualizing him. Every time I manage to conceptualize something, I am using my intelligence. Knowledge means power, domination, control, supremacy over what has been known. If I conceptualize God, I set myself in a position to know him. But this is an impossible task. Therefore, Dionysius proposes to say nothing positively about him and then letting him be what he is.

Dionysius states that the only way we could approach God, letting him be God, is through negative theology. This consists in avoiding any affirmative statement about God and, rather, it would bring into focus what God is not. By saying what God is not, one will realize that nothing will be said about him and therefore, no one will attempt to de- 
fine him in terms of concepts. In short, Negative theology, also known as Apophatic theology, is a theological approach that describes God by negation, speaking of God only in terms of what He is not (apophasis) rather than presuming to describe what God is and avoiding to describing him conceptually.

This type of approach gets closer to what we call mysticism, or prayer, although we recognize that both terms might have different - but not excluding - meanings. Negative theology uses silence as the most powerful sign of respect. John Caputo affirms that "by promising to efface, negative theology traces out its place within the archipromise, within the trace" 37 . Words here do not play an important role. Contemplation and prayer are forms of relationship, not explanation or oral description in which he who engages in prayer will be engaging in a true encounter with God by letting him be what he is, and not what I think he is. No one gains epistemic knowledge by praying or saying what God is not. In addition, one is beyond the realm of sensorial perception while contemplating. Contemplation means that God is ineffable, inexpressible and beyond human control, and theological understanding is absolutely not important here. What really matters is that we are neither affirming something about God nor reducing him in terms of conceptual understanding. John Caputo writes ${ }^{38}$ :

So the double bind of negative theology is a double

\footnotetext{
${ }^{37}$ John Caputo, The Prayers and Tears of Jacques Derrida. Religion without Religion, (Indianapolis: Indiana University Press, 1997), 32

${ }^{38}$ John Caputo, The Prayers and Tears of Jacques Derrida. Religion without Religion, 46
} 
save. When negative theology says that God is beyond every name we give to Him, that is a way of saying "God such as he is," beyond all idols and images, a way of "respond[ing] to the true name of God, to the name to engages in negation.

However, it is a way of understanding God that did not come forward without criticism. Derrida probably is the most important contemporary philosopher to raise concerns about the negative theology.

Derrida points out that negative theology "has come to designate a certain typical attitude toward language, and within it, in the act of definition or attribution, an attitude toward semantic or conceptual determination." ${ }^{39}$ First of all it comes to mind that, according to Derrida, negative theology is a language that has specific determinations and it seems to follow an apparatus of methodological rules. Moreover, it ends up being a simulation or parody or mechanical repetition. ${ }^{40}$ There is also an automatic ritualistic ${ }^{41}$

\footnotetext{
${ }^{39}$ Harold Coward and Toby Forshat, Derrida and Negative Theology - original text by Derrida, (Albany: State University of New York Press, 2001) 74

${ }^{40}$ Harold Coward and Toby Forshat, Derrida and Negative Theology, 75

${ }^{41}$ Harold Coward and Toby Forshat, Derrida and Negative Theology, 75. Derrida points out negative theology may have three types of objection: "A). You prefer to negate. You affirm nothing. You are fundamentally nihilist, or even an obscurantist. Neither knowledge nor even theology will progress in this way. Not to mention atheism of which one has been able to say in an equally trivial fashion that it is the truth of negative theology. B). You abuse a simple technique; it suffices to repeat: $X$ is no more than this, than that, $X$ seems to exceed all discourse or predication, and so on. This comes back to speaking, in order to experience speech. Or, more seriously, you speak thus with an eye to writing, since what you write then does not even merit being said. This second critique already appears more interesting and more lucid than the first: to speak for the sake of speaking, to experience what happens to speech through speech itself, in the trace of a sort of quasi tautology, is not entirely to speak in vain and to say nothing. It is perhaps to experience a possibility of speech which the objector himself must presuppose at the moment when he addresses his criticism. To speak nothing is not: not speak. Above all, it is not the speak to no one. C). [...] from the moment a proposition takes a negative form, the negativity that manifests itself need only be pushed to the limit, and it a least resembles an apophatic theology. [...] every negative sentence Cont.
} 
element, and the lack of being true or false allows prayer to say nothing about nothing. Apparently, Derrida accepts that negative theology does not completely dismiss the determination and therefore, talks about God. He thinks that negative theology still attempts to give an identity to which our prayers are directed. There is a Being beyond Being towards which someone contemplates and prays for and this makes us think that negative theology may not accomplish completely what has been promised. Negative theology says nothing positive about God and it claims not to do what it does all the time. Perhaps also apophatic theology is meant to honour silence and something crucial for our lives. Derrida objects also that by suspending the supposedly ultimate and freestanding negation of implicitly and surreptitiously smuggling in and re-establishing and affirmation the apophatic represents a sort of paradoxical hyperbole, transmutes into affirmation its negativity, often call to mind the sentence, the decision or verdict, the statement. ${ }^{42}$

\section{MARION'S RESPONSE}

Marion's response to Derrida's objection is rather complex and long. I will attempt to summarize here although I shall not proceed in a deep way. Such endeavor is not the main purpose of this work. Marion argues that praying and praise cannot be understood as mere disguised predication

would already be haunted by God or by the name of God, the distinction between God and God's name opening up the very space of this enigma. If there is a work of negativity in discourse and predication, it will produce divinity. God would be the truth of all negativity."

${ }^{42}$ John D. Caputo and Michael J. Scanlon, God, the gift and post modernism, (Indianapolis: Indiana University Press, 1999), 25 
while pretending to name God, the one to which I direct my praise. Actually, writes Marion, "but can prayer pure and simple be accomplished without naming - giving name, however improper? No doubt we can contest this, given that no prayer can pray without giving a name, without acknowledging an identity even and especially an improper one. Nor only naming does not contradict the invocation of the prayer, but without the invocation the prayer would be impossible - what would it mean to praise without praising anyone, to demand without demanding from anyone, to offer a sacrifice without offering to anyone?"43

According to Marion, prayer does not consist only of invoking someone to be within the boundaries of our common language. Prayer exceeds these boundaries and acknowledges that God is, already among us. In short, prayer consists in "setting out with an intention to approach in all impropriety". ${ }^{44}$ In addition, praise and prayer do not consist in naming something to someone. Therefore, we are using here the metaphysical sense of the language.

Is mystical theology really inscribed within the horizon of Being? Marion responds that Dionysius brought into focus that neither "Being" or "being" offered a proper name for God. The platonic notion of goodness has been applied to Being improperly, and Marion does not grant this privilege to what goodness is supposed to be. Goodness does not overstep the essence of God and Marion acknowledges that "God without Being does not end up thinking good-

\footnotetext{
${ }^{43}$ John D. Caputo and Michael J. Scanlon, God, the gift and post modernism, 29

${ }^{44}$ John D. Caputo and Michael J. Scanlon, God, the gift and post modernism, 30
} 
ness otherwise that Being - goodness remains undetermined and, in any case, without essential impact. ${ }^{45 "}$ But Marion points out that by refraining to refer to God as a Being one will no longer be in the realm of saying or non saying but, rather, hearing. Dionysius himself points out the "bountiful beauty bids". ${ }^{46}$ Mystical theology, therefore, does not surpass what Being is, but acts as a non-objects determination in such a radical way that God keeps my gaze, my feelings and does not inform me, teach me anything but nevertheless shapes my life far more deeply than words. Therefore, negative theology should not be reproached for not knowing what to say and how to say it. It is a matter of relationship, not words. God is known by knowing - since to believe is an act of reason - and also by unknowing. Scriptures say that God cannot be seen (Exodus 33:23) because nothing finite can overtake the infinite without perishing. It seems that the condition to know God is the condition to remain somehow ignorant of his essence, his concept or his presence. The idolatry of the concept is the same as that of the gaze, as long as the latter keeps it to itself. Christian tradition has shown that is not necessary to know the name of the Most High where eyes and flesh cannot attain what is invisible and ineffable. If God can be known by not being known, something remarkable comes forward. Negative theology attempts to attain and understand this not knowing by presupposing that the human mind doesn't have anything better. To know him without knowing him is knowing by ignorance, to know that one

\footnotetext{
${ }^{45}$ John D. Caputo and Michael J. Scanlon, God, the gift and post modernism, 32

${ }^{46}$ John D. Caputo and Michael J. Scanlon, God, the gift and post modernism, 32
} 
does not know, to know incomprehensibility as such by knowledge that comes from the ignorance. Marion asserts that incomprehensibility belongs to the formal essence of God since comprehending him would put our knowledge at the same level as God's. However, by theology of absence, Marion does not mean the non-presence of God but the name which gives God, which is given as God, serves to shield God from presence - weakness designating God at least as well as strength - offers him precisely as an exception to presence ${ }^{47}$. We can perceive that the negative theology is not an affirmation in disguise but truly a way of granting God what belongs to him. However, negative theology itself can be misunderstood if it is seen merely as a negation rather than the experience of incomprehensibility. In short, negative theology ought to overcome negation and settle in the contemplation.

\section{CONCLUSION}

One of the features humanity carries is the face. Eyes reveal the soul, the feelings, and the humor and are able to reveal much more about a person's psychology. One should be able to grasp one's will by staring at the face and noticing how that person behaves and acts. From a scientific point of view, we know that our world is visible because of matter, and we tend to grant too much to what we can touch and see. On the other hand, we resist believing in what is beyond the face. Perhaps we could ask: What is

\footnotetext{
${ }^{47}$ John D. Caputo and Michael J. Scanlon, God, the gift and post modernism, 37
} 
more real - the visible or the invisible? We know perfectly that we often deal with invisible realities - such as thoughts, intelligence, and so on - but few people really open themselves to ask why such things exist and how they relate to the physical reality.

Dealing with visible and invisible things motivates us to change perspective and question what really matters to us. What would the reader's reaction be like if someone you know offers to give you money in exchange for your love? What's worth more? It seems to me that the most valuable things we have are invisible and the visible is a mere representation or sign of something more excellent, more meaningful and deeper. We know that for what really matters, the invisible, the visible can be a sign of a more perfect gift that is invisible, but real: my love, my acknowledgement and my friendship. As long as I live, my love cannot be defeated, even by death. In fact, I can still love a relative that passed away, even though I know that he or she will not respond to my love. I still love. When I die, someone else will continue to love me and the love chain will endure and this is not a material thing. Love cannot be defeated. Kierkegaard wrote that humans are unable to deliver a perfect gift since the true one is from above. God is excess, but excess of love.. In addition, if someone had offered me millions of dollars in order to buy my love, that one would be despised because my love is not for sale. Instead, if someone starts smiling at me, gets to know me more and deserves my trust, I can love for free and deliver all my being to live that love with intensity.

What I have to say is that the controversy of the gift, discussed in this essay, has its final answer in love. Excess of 
intuition and no concept leads to experience what is really invisible, but is more real than the universe.

\section{REFERENCES}

Harold Coward and Toby Forshat. Derrida and Negative Theology - original text by Derrida, (Albany: State University of New York Press, 2001)

Michael Watts, Kierkegaard (Oxford, Oneworld Publications, 2003)

Jacques Derrida. The Gift of Death (Chicago: The University of Chicago Press, 2007)

Jean-Luc Marion. In Excess, studies of Saturated Phenomena (New York: Fordham University Press, 1992)

2002)

Being Given (Stanford: Stanford University Press,

. In: excess:studies of saturated phenomena (New York: Fordham University Press, 2004)

. The visible and the revealed (New York: Fordham University Press, 2008)

John D. Caputo and Michael J. Scanlon, God, the gift and post modernism, (Indianapolis: Indiana University Press, 1999)

John Caputo, The Prayers and Tears of Jacques Derrida. Religion without Religion, (Indianapolis: Indiana University Press, 1997)

Robyn Horner. Rethinking God as a Gift (New York: 
Fordham University Press, 2001)

Søren Kierkegaard. Training in Christianity, (Princeton: New Jersey Princeton University Press, 1967)

. Eighteen upbuilding discourses (Princeton: Princeton University Press, 1992)

. Philosophical Fragments, (Princeton: New Jersey Princeton University Press, 1974), 59

- Fear and Trembling, (Princeton: New Jersey Princeton University Press, 1968)

. The Sickness unto Death, (Princeton: New Jersey Princeton University Press, 1969)

. Either/Or, (Princeton: New Jersey Princeton University Press, 1987)

. Concluding Unscientific Postscript, (Princeton: New Jersey Princeton University Press, 1968)

Simon D. Podmore. Kierkegaard and the self before God (Indianapolis: Indiana University Press, 2011) 